\title{
UN NUEVO ANÁLISIS IUSFILOSÓFICO Y CANÓNICO DE la Constitución Apostólica “Ex CORDE ECClESIAE” DEL PAPA JUAN PABLO II A 25 AÑoS DE SU EMISIÓN*
}

\author{
[A New Iusphilosophical and Canonical Analysis of 'Ex Corde Ecclesiae'
} Apostolic Constitution of Pope John Paul Ii 25 Years After it Was Issued]

\author{
Cristóbal OrRego SÁNCHEZ** \\ Pontificia Universidad Católica de Chile
}

\begin{abstract}
RESUMEN
Con ocasión del $50^{\circ}$ aniversario del Concilio Vaticano II y los 25 años de la constitución apostólica "Ex corde Ecclesiae", se estudia la identidad y la misión de las universidades católicas, a la luz del derecho canónico y del reciente magisterio eclesiástico. Con este fin, se presenta la realidad pasada y presente de las instituciones católicas de educación superior; se analiza, desde una perspectiva jurídica y a la luz de su origen y de sus actuales
\end{abstract}

\begin{abstract}
On the occasion of the $50^{\text {th }}$ anniversary of the Second Vatican Council and the $25^{\text {th }}$ anniversary of the apostolic constitution "Excorde Ecclesiae", the identity and mission of catholic universities is studied in the light of canonical law and the recent ecclesiastical magisterium. The past and current reality of catholic higher education institutions is, therefore, shown; both, from a legal perspective and considering their origin and current
\end{abstract}

RECibido el 27 de octubre y ACEPTADo el 22 de diciembre de 2014

* Este artículo es resultado del Proyecto de Investigación "Las universidades católicas en el nuevo milenio: identidad y misión a medio siglo del Concilio Vaticano II" (DPCC 1623/2012). Agradezco a la Dirección de Pastoral y Cultura Católica y a la Vicerrectoría de Investigación de la Pontificia Universidad Católica de Chile por el apoyo recibido.

** Licenciado en derecho por la Pontificia Universidad Católica de Chile; doctor en derecho por la Universidad de Navarra. Profesor de Filosofía del Derecho y Derecho Natural en la Pontificia Universidad Católica de Chile. Correo electrónico: corregos@ uc.cl. 
circunstancias, cuál deba ser la genuina identidad y misión de tales instituciones, $\mathrm{y}$, finalmente, se expone el magisterio más reciente del papa Francisco I sobre la materia.

Palabras Clave

Universidad - Universidades católicas - Universidades civiles. circumstances, its genuine identity and the mission of said institutions is analysed and, finally, this work presents the most recent magisterium of Pope Francis I on this matter.

KEYWORDS

University - Catholic universities Lay universities.

\section{INTRODUCCIÓN}

La Universidad Católica de Lovaina, en el año 2012, sometió a votación si seguiría o no siendo oficialmente católica, y decidió que continuaría siéndolo, pero con autonomía respecto de la Santa Sede ${ }^{1}$. La Pontificia Universidad Católica del Perú, tras años de enseñar doctrinas contrarias a la católica y de negarse a adaptar sus estatutos a Ex corde Ecclesiae, ha sido objeto de un Decreto oficial de la Santa Sede que le prohíbe usar los títulos "Pontificia" y "Católica". La Universidad de Notre Dame (Indiana), quizás el más visible símbolo de la enseñanza superior católica en Estados Unidos, ha conferido el Doctorado "honoris causa" al presidente Barack Obama, uno de los más firmes promotores del aborto y la ideología de género en el mundo 3 . Estos son solamente tres ejemplos mundialmente famosos de universidades que se desvían de su misión católica; pero la situación es crítica en la mayoría de las universidades de Estados Unidos y en no pocas de América y de Europa. Sucede que la encomiable buena voluntad de mantener la identidad católica, que se expresa en ceremonias devocionales y en discursos oficiales, subsiste junto a un conflicto subterráneo, no resuelto, entre los miembros de las universidades católicas - profesores, estudiantes, funcionarios, autoridades- por causa de divergentes interpretaciones de lo que estas instituciones son y deben ser, así como por diversas apreciaciones de la situación presente: lo que para

${ }^{1}$ Disponible en: http://www.kuleuven.be/english/news/conclusions_of_identity_debate, [fecha de consulta: 15 de julio de 2014].

${ }^{2}$ Disponible en: http://www.aciprensa.com/Docum/decretopucp.pdf, [fecha de consulta: 15 de julio de 2014]. El caso sigue en desarrollo. Recientemente la Santa Sede ha comisionado a tres cardenales (Erdö, Ezzati y Lacroix) para que ayuden a hallar una solución de consenso. Disponible en: [http://vaticaninsider.lastampa.it/es/en-elmundo/dettagliospain/articolo/pucp-33820, [fecha de consulta: 15 de julio de 2014].

${ }^{3}$ Véase Miscamble, Wilson, For Notre Dame. Battling for the Heart \& Soul of a Catholic University (South Bend, St. Agustine’s Press, 2013), pp. 127-128. 
algunos es positivo -signo de apertura de la Iglesia a nuevas realidades-, resulta para otros negativo -señal de concesiones indebidas a la mundanidad espiritual, a la injusticia social y al abandono de la fe y de la moral $-^{4}$.

Ofrecemos este artículo como una ayuda para esclarecer la identidad y misión de las universidades católicas, especialmente desde una perspectiva normativa. La primera sección proporciona una síntesis histórica que permite comprender la situación presente y la vigencia del ideal de las universidades católicas, para pasar luego al análisis propiamente jurídico de la identidad de las universidades católicas. Terminaremos con una breve sección destinada a mostrar el refuerzo de esta identidad católica por el Magisterio, fuerte y original, del Papa Francisco.

\section{Fragmentación POSTMOderna: \\ CONTEXTO HISTÓRICO-CULTURAL DE LA IDENTIDAD Y MISIÓN DE LAS UNIVERSIDADES CATÓLICAS}

La expresión "universidad" hace referencia a un conjunto de personas (universitas magistrorum et scholarium) y de saberes (universitas scientiarum) que expresa el carácter universal de la institución en sus orígenes ${ }^{5}$. El adjetivo "católico" significa, según su etimología griega, precisamente "universal", es decir, algo que, siendo esencialmente una sola cosa, se concreta o realiza en muchos casos concretos con variaciones accidentales de tiempo y de lugar, que no destruyen, sino que, más bien, enriquecen, con su multiforme diversidad, esa universalidad. La Iglesia es el modelo de la catolicidad: "En virtud de esta catolicidad, cada una de las partes colabora con sus dones propios con las restantes partes y con toda la Iglesia, de tal modo que el todo y cada una de las partes aumentan a causa de todos los que mutuamente se comunican y tienden a la plenitud de la unidad"6. La Iglesia existe y se realiza en y a partir de las iglesias particulares, que concretan lo propio de la única Iglesia universal en diversos lugares y tiempos, con su multiforme riqueza de tradiciones y de culturas que no destruyen esa unidad fundamental ${ }^{7}$. En consecuencia, la

${ }^{4}$ Esta diversidad de enfoques puede verse en los artículos y comentarios recogidos en Langan, John, Catholic Universities in Church and Society: A Dialogue on "Ex corde Ecclesiae" (Washington, Georgetown University Press, 1993).

${ }^{5}$ Martínez-Echevarría, Íñigo, La relación de la Iglesia con la Universidad en los discursos de Juan Pablo II y Benedicto XVI: una nueva aproximación jurídica (Roma, EDUSC, 2010), pp. 62-66.

${ }^{6}$ Constitución dogmática del Concilio Vaticano II sobre la Iglesia "Lumen Gentium" (1965), n. 13.

${ }^{7}$ Encuentro del papa Francisco I con el mundo de la cultura en el Aula Magna de la Pontificia Facultad Teológica de Cerdeña (22 de septiembre de 2013), números 130134. 
expresión "universidad católica” es, desde cierto punto de vista - a mi modo de ver-, un pleon asmo engañoso: expresa reduplicativamente la esencia genuina de la universidad como institución, de acuerdo con sus orígenes; pero sugiere, a la vez, que se trata solamente de un tipo particular o de una especie restringida dentro del género de las universidades. Esta paradoja se debe a que las universidades católicas surgen, con esta denominación de contraste cultural y doctrinal, como consecuencia de la fragmentación cultural moderna y precisamente para enfrentarla. En el mundo postmoderno no existe ninguna universidad que sea universal de facto; pero el conjunto de todas ellas -la universitas universitatorum, si se me permite el neologismopuede aspirar a revivir ese alto ideal.

Un repaso de las etapas de la historia de la universidad como institución nos lleva a comprender mejor la paradoja del presente postmoderno en que nos hallamos.

La existencia de escuelas de sabiduría y ciencia, con un maestro y sus discípulos, y con sus sucesores en el tiempo, puede rastrearse hasta muy antiguo, tanto en Oriente - piénsese en Confucio ${ }^{8}$ - como en Occidente: Sócrates, Platón y su Academia ${ }^{9}$, Aristóteles y el Liceo ${ }^{10}$ y las otras escuelas filosóficas ${ }^{11}$. Sin embargo, estas escuelas no han tenido una continuidad institucional hasta nuestros días. El origen de las actuales universidades se halla en los modelos de Bolonia y París, que se fueron extendiendo por Europa a partir del siglo $\mathrm{XI}^{12}$. "Aunque se pueden citar instituciones de enseñanza anteriores que más tarde dieron lugar a centros que hoy son universitarios (por ejemplo, la Universidad de Qarawiyyin -en Fez, Marruecos-; la de Hunan -en Changsha, China-; la de Al-Azhar -en El Cairo, Egipto-, todas ellas fundadas antes de terminar el siglo $\mathrm{X}$ ), fueron las universidades europeas fundadas entre los siglo XI y XV -con unos caracteres propios que no tenían equivalente ni en el mundo clásico, ni en el bizantino ni en el árabe-, las que sentaron las bases del modelo de universidad que después se difundirá por todo el mundo"13. Naturalmente puede haber un interés ideológico en quitar el mérito de la fundación de las primerias universidades, en sentido propio y pleno, a la

${ }^{8}$ Parain, Brice, Historia de la filosofía (México, Siglo XXI, 1972), I, pp. 243-248.

${ }^{9}$ Parain, Brice, Historia de la filosofía (México, Siglo XXI, 1972), II, pp. 51 y ss.

${ }^{10}$ Ibíd., pp. 185 y ss.

${ }^{11}$ Las más conocidas son el estoicismo, el epicureísmo y el neoplatonismo. Sobre el tema, véase: PARAIn, Brice, Historia de la filosofía (México, Siglo XXI, 1972), II, pp. 267 ss. Y más tarde los comentaristas árabes de Aristóteles (como Avicena y Averroes) y judíos (como Maimónides): ahí mismo, pp. 219 ss.

${ }^{12}$ De La Cruz, Emilio, Lecciones de historia de las universidades (Madrid, Civitas, 1987), pp. 19-25.

${ }^{13}$ Martínez-Echevarría, I., cit. (n. 5) p. 37. 
cristiandad latina y, en definitiva, a la Iglesia Católica. Este interés a menudo confunde la historia de las universidades con la historia de la educación ${ }^{14}$. A nosotros nos parece, en una interpretación difundida, que, en realidad, las instituciones de enseñanza precedentes constituyen la prehistoria de la universidad como institución.

Una característica interesante -sobre todo, por la perspectiva de este artículo- de la historia de las primeras universidades -Bolonia, París, Oxford, etc.-, que constituirá luego un sello común de todas ellas, es su origen esencialmente jurídico. Ciertamente, existe una realidad social de maestros y discípulos -en el caso notable de Bolonia, de estudiantes que se asocian para contratar maestros- y una realidad científica y profesional de disciplinas enseñadas al más alto nivel: Artes (filosofía), Teología, Derecho y Medicina. Sin embargo, esa realidad social viva no se constituye como un organismo au tón o mo dentro de la respublica christiana, mientras no se configura jurídicamente como independiente respecto de las autoridades civiles y eclesiásticas. Las primeras universidades no fueron fundadas en un momento preciso, sino que surgieron y se consolidaron progresivamente, hasta obtener - porque ya poseían auctoritas científica y fuerza social- el reconocimiento pontificio que les confirió formalmente su autonomía jurisdiccional ${ }^{15}$. La universidad como institución nace, pues, del corazón de la Iglesia entendida como Pueblo de Dios: de su vitalidad interna, reconocida y apoyada por el Vicario de Cristo, con su potestad jurisdiccional universal y suprema.

Poco después nacen las primeras universidades fundadas expresamente por el emperador y el papa. El emperador Federico II fundó la Universidad de Nápoles en 1224, y el papa Gregorio IX creó la Universidad de Toulouse en 1229. En otras partes, la autoridad civil y la eclesiástica local fundan universidades conjuntamente. Incluso cuando las instituciones de enseñanza superior surgen por iniciativa de profesores o estudiantes, o de autoridades locales, finalmente solicitan al Romano Pontífice los privilegios de las primeras universidades: el ius ubique docendi, la autonomía jurisdiccional, etc. El derecho de enseñar en todas partes facilitó la movilidad de estudiantes y profesores, y el surgimiento de un rasgo clave de la universidad como realidad cultural nueva: su universalidad. La universidad es una sola; es una sola gran comunidad universal de maestros y discípulos, que se concreta en instituciones locales autónomas y, a la vez, abiertas, no cerradas en sí mismas ${ }^{16}$.

${ }^{14}$ Véase Iyanga, Augusto, Historia de la Universidad en Europa (Valencia, Universitat de Valencia, 2000), p. 8.

${ }^{15}$ Martínez-EchevarRía, I., cit. (n. 5) pp. 42-57.

${ }^{16}$ Véase d'Ors, Álvaro, Nuevos papeles del oficio universitario (Madrid, Rialp, 1980), p. 27. 
Todas las universidades particulares actualmente existentes -cualquiera sea su tamaño y sin importar sus limitaciones- proceden de ese núcleo originado en la cristiandad latina. Se podría trazar una suerte de "sucesión académica” universitaria - por analogía, evidentemente, con la sucesión apostólica ${ }^{17}$ - desde la Universidad de los Andes, por ejemplo, fundada en Santiago de Chile, en 1989, por profesores procedentes de la Pontificia Universidad Católica de Chile y de la Universidad de Chile, hasta los primeros maestros que, procedentes de las universidades europeas -sobre todo españolas-, fundaron las primeras universidades americanas en Lima y en Ciudad de México, y luego en Santiago de Chile ${ }^{18}$.

La universidad, antes de que se produzcan los diversos procesos de fragmentación de la modernidad, se caracteriza así: $i$ ) es una universitas magistrorum et scholarium, es decir, una comunidad de maestros y estudiantes, unidos por el afán de saber para conocer la verdad en la máxima medida posible y para enseñarla y para aprenderla; $i i$ ) es una universitas scientiarum, es decir, un ámbito de cultivo de tendencialmen te todas las ciencias superiores, tanto especulativas (filosofía, teología) como prácticas (derecho civil y canónico, medicina $)^{19}$; iii) la identidad cristiana-católica necesariamente impregna toda la institución, pues ésta constituía un cuerpo vivo dentro una sociedad cristiana; $i v$ ) la au tonomía jurídica con relaciones en parte de dependencia (communio doctrinal y jerárquica) y en parte de autonomía respecto de las autoridades eclesiásticas y civiles.

Javier Hervada observa que "hasta tiempos recientes no había más que universidades, sin calificativos diferenciales" ${ }^{20}$. No tenían sentido las oposiciones de conceptos como pública/privada, estatal/eclesiástica, secular/ católica, etc. "Nacidas en pleno régimen de cristiandad, las universidades cultivaron sus respectivas ciencias bajo la inspiración de la fe católica

${ }^{17}$ La sucesión apostólica es la continuidad ininterrumpida del Colegio de los Obispos cum Petro et sub Petro, mediante la ordenación episcopal válida, con el Colegio de los Apóstoles constituidos por Jesucristo, quienes fueron los primeros Obispos. Véase el Catecismo de la Iglesia Católica, nn. 880-887.

${ }^{18}$ Véanse: Orellana, Miguel, Enriquecerse tampoco es gratis. Educación, modernidad y mercado (Santiago, Editorial Universidad de Santiago de Chile, 2014), pp. 37-45; y Bravo Lira, Bernardino, La universidad en la historia de Chile: 1622-1992 (Santiago, Pehuén, 1992), pp. 24-47.

${ }^{19}$ Como dijo Juan Pablo II, en su "Discurso" del 18 de abril de 1982: "En efecto, no es necesaria que cada institución cultive todas las ciencias (v.gr. Bolonia comenzó con Derecho y no tuvo Teología hasta el siglo XIV), sino que se cultiven algunas con espiritu de universalidad y siempre en el contexto, al menos intencional, de todas las demás". Citado por MARTÍnez-EcheVARRÍA, I., cit. (n. 5) p. 66.

${ }^{20}$ Hervada, Javier, "Vetera et Nova”. Sobre el estatuto de las universidades católicas y eclesiásticas (2a edición, Pamplona, Navarra Gráfica Ediciones, 2005), pp. 345-360. 
e intervinieron activamente - fundamentalmente a través de las Facultades de Teología- en las disputas que, sobre cuestiones conexas con la fe o la moral católicas, se fueron presentando" 21 .

Las universidades no eran, en rigor, ni estatales ni eclesiásticas, porque "su a u to n o mía [...] entonces significaba -además de las libertates academicaesu carencia de inserción en la organización estatal o eclesiástica, conformándose como corporaciones sui iuris, aunque bajo la protección papal y real"22.

La ruptura de la Cristiandad, iniciada por Martín Lutero en el siglo XVI, dio origen al fenómeno de la confesionalidad estatal, que se extendió a las universidades. La confesionalidad religiosa, exigida por el Estado, "se garantizaba por la professio fidei exigida a los profesores o mediante otras fórmulas" ${ }^{23}$. El intento de garantizar la adhesión de la universidad -de los maestros y discípulos, obligados por el juramento o excluidos formalmente por la imposibilidad moral de prestarlo- a la verdade ra fe cristiana (¿cuál?) significó una disminución de la autonomía de las corporaciones frente a la autoridad civil encargada de imponer esa confesionalidad. La división religiosa debilitó a la Iglesia, fortaleció al Estado y amenazó la vitalidad de los cuerpos vivos de la sociedad civil.

Después de las revoluciones liberales, paulatinamente fueron desapareciendo los juramentos confesionales, y el Estado fue asumiendo el control de numerosas universidades ${ }^{24}$. El laicismo, que pretendía garantizar la libertad de pensamiento, simultáneamente impulsó la estatalización de las corporaciones -algunas con mayor, otras con menor autonomía legal o de facto- y frecuentemente, aunque no en todas partes por igual, la supresión de los estudios de teología y derecho canónico. Se produce así la identificación conceptualmente errónea- entre universidad pública y universidad estatal. Como consecuencia, las universidades que, en el futuro -ya en el siglo XIX, y especialmente en el siglo XX-, sean fundadas al margen del sistema integrado de universidades estatales serán consideradas universidades privadas.

Asistimos claramente, pues, a un proceso de dislocación de la universidad como institución universal. Paralelamente, la acelerada especialización de las ciencias -subdivisión tras subdivisión - y la reducción de la filosofía a una disciplina especializada, además de la frecuente expulsión de la teología del claustro universitario - debida al prejuicio ateo del cientificismo laicista-, condujo a la actual crisis de fragmentación y atomización del $\operatorname{saber}^{25}$. Estos

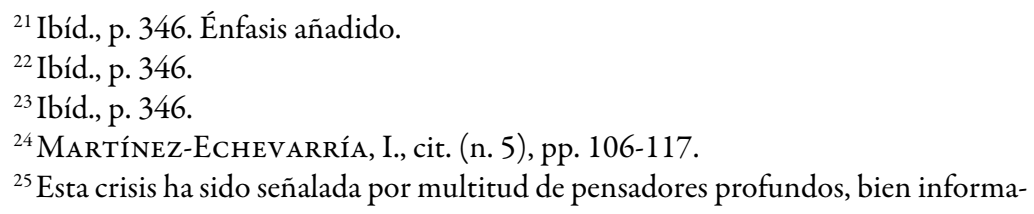


fenómenos se dan en el seno de la cultura postcristiana y postmoderna, donde masas desorientadas de hombres -muchas veces seguros de sí mismos, pero tantas otras dramáticamente conscientes de su inseguridad- descreen de la trascendencia; reducen el conocimiento verdadero a lo fenoménico; aprecian la enseñanza-aprendizaje solamente para finalidades pragmáticas o hedonistas (v.gr. la producción, el enriquecimiento, el disfrute a corto plazo); y se ven abocadas a un nihilismo carente de esperanza, vacío y negro. El ideal de la universidad sigue presente en muchos que no saben cómo darle un sentido, puesto que las cuestiones fundamentales, a las que antes se ordenaba el ejercicio crítico de la razón y la búsqueda de la verdad -como la cuestión de Dios, la inmortalidad del alma, la verdadera religión, la libertad, el bien y el mal, etcétera-, han sido abandonadas ya en manos de especialistas, ya a su suerte en el ámbito de las libérrimas opciones subjetivas.

En este contexto cultural, ya desde el siglo XIX, la Iglesia Católica se ocupó de rescatar la cultura-como San Benito-, aunque de momento no fuera más que para sus fieles. Bajo el impulso de Gregorio XVI y de León XIII, se fundaron universidades formalmente católicas de estudios civiles -esto es, dirigidas a formar, sobre todo, a los católicos laicos con profundidad científica y en armonía con la fe- y universidades o facultades de estudios eclesiásticos -sobre todo para clérigos y religiosos como parte de una profunda formación teológica, canónica, etc.-.

Se ha de añadir que, a partir de la masificación de las universidades desde los años 60 del siglo XX, han surgido, desde la sociedad civil, empeños universitarios no estatales y no eclesiásticos, con finalidad cultural -con o sin fines de lucro-, con inspiraciones filosóficas, ideológicas o religiosas de los más variados signos: universidades de inspiración católica, evangélica, islámica, masónica, liberal, neomarxista, o ninguna en especial. Todas ellas, en algún nivel de su discurso, aspiran a ser genuinas universidades, y de hecho entroncan, por los profesores que contratan, con la gran "sucesión académica" universitaria ${ }^{26}$.

La paradoja resulta evidente para cualquiera que estudie esta historia y el punto de llegada de la universidad en el siglo XXI: fragmentado, disperso, desarticulado. Ya no existe la universidad simpliciter. Ninguna institución universitaria particular puede considerarse genuina y completa encarnación de la universidad según el ideal fundacional. Consideremos un par de muestras sencillas. La universidad como negocio lucrativo -legitimo como empresa comercial que ofrece un adecuado servicio formativo para el

dos y preocupados. Véanse: VIAL, Juan de Dios, No debemos descuidar la interdisciplinariedad, en Revista Universitaria, 50 (1995), pp. 4-6; Llano, Alejandro, Repensar la Universidad, en Humanitas, 33 (2004), pp. 33-41.

${ }^{26}$ Véase la nota 17. 
mundo del trabajo- no puede realizar el mismo ideal universal de investigación y transmisión desinteresada de todas las ciencias, que exige cada vez más apoyos económicos y no permite excedentes. Por ese mismo objetivo de la ciencia, las universidades no lucrativas se ven igualmente sometidas a la presión de los intereses económicos externos.

Asimismo, una universidad estatal pluralista, que a veces excluye injustificadamente la teología católica y que con justicia no impone limitaciones confesionales a sus profesores o estudiantes, acoge en su seno -al menos, cuando no es cooptada por un sector ideológico, como a veces sucede- una representación más amplia de las posiciones vigentes en el debate público (v.gr., profesores pro-vida y profesores pro-aborto; neomarxistas, ideológicos del género, iuspositivistas, iusnaturalistas, cristianos, musulmanes, judíos, etc.). En tales casos, ella crea un ámbito de facto más universal para la confrontación académica sobre los asuntos públicos, salvo en aquellos lugares donde, de facto también, se imponen criterios liberales (o incluso totalitarios) sobre lo "políticamente correcto" y se excluye a los profesores que no se conforman. En cambio, una universidad católica fiel a su identidad y a su misión ${ }^{27}$, aunque justificadamente restringirá el pluralismo ideológico interno de acuerdo con su ideario ${ }^{28}$, como contrapartida será más completa y universal en su apertura a la trascendencia, en su inclusión necesaria de la teología católica y de la filosofía cristiana en diálogo con todas las disciplinas, en la formación integral de sus estudiantes, en la práctica de la caridad cristiana y de las obras de misericordia, y también en la inclusión de profesores de posiciones políticas muy diversas y antagónicas excluidas de universidades con ideario contrario.

Naturalmente, hay una cuestión de fondo que resulta determinante para juzgar la superioridad absoluta de una universidad sustancialmente católica en comparación con una universidad sustancialmente laicista (que excluya la teología y la formación integral, también religiosa, de los estudiantes): si la (supuesta) Revelación custodiada por el Magisterio de la Iglesia es un hecho verdadero o falso. Si es verdadero, cualquier universidad carente de contacto con ese hecho y que no profundiza en él es eo ipso menos universal; carece de lo esencial, y es, por ende, menos universidad ${ }^{29}$. Por el contrario, si la pretensión de la Iglesia Católica es falsa, la presencia de restricciones derivadas de semejante engaño -sobre asuntos fundamentales para la vida y la forma-

${ }^{27}$ Véase todo nuestro desarrollo en la sección II.

${ }^{28}$ Código de Derecho Canónico (1983), c. 810.

${ }^{29}$ Véase MAcInTyre, Alasdair, Three Rival Versions of Moral Enquiry. Encyclopaedia, Genealogy and Tradition (Notre Dame, University of Notre Dame Press, 1990), pp. 5-8, 145-150, 173-180; Finnis, John, ¿Acaso la universidad corrompe la juventud? en El Derecho. Diario de Doctrina y Jurisprudencia, 13 (2012) 141, pp. 3-4. 
ción del nombre- ha de juzgarse cuando menos como una distracción inútil y supersticiosa, y más exactamente como una interferencia inadmisible con la ciencia y con la educación racional y ética de la juventud. Una institución así inspirada no puede ser una genuina universidad, porque está mutilada en sus fundamentos.

La imposibilidad de disminuir esta cuestión en una sede imparcial -no hay neutralidad entre catolicismo y laicismo o ateísmo-, así como la existencia de un pluralismo ideológico y religioso ineliminable defacto ${ }^{30}$, hacen aconsejable, a mi modo de ver, sostener en libertad la pluralidad de instituciones universitarias y procurar que el polied ro global resultante sea un reflejo del ideal de universidad no existente en ninguna institución particular ${ }^{31}$. Asimismo, la estrecha colaboración -más o menos estrecha según las circunstancias- entre universidades muy distintas - por su orientación ideológica o religiosa, por su país, por sus especialidades científicas...- permitirá a sus miembros constituir, a partir de su propia comunidad universitaria particular -con su identidad no adulterada y con conciencia de sus límites-, una verdadera y universal universitas magistrorum et scholarium en pos de la universitas scientiarum.

Desde el presupuesto de la verdad de la fe y de la armonía entre la fe y la razón ${ }^{32}$, en cambio, podemos movernos con la seguridad de que una universidad sustancialmente católica es plenamente universal: no excluye a ninguna persona -se autoexcluye solamente quien no respeta la esencia de la universidad- y no excluye ninguna verdad teológica, filosófica o científica. Tampoco excluye, sino que exige, el diálogo y, si es necesario, el debate respetuoso con quienes propugnan o rechazan la verdadera fe. Sin embargo, esta universidad verdadera -i.e., la sustancialmente católica-ha de ser consciente de su ineliminable limitación de facto y salir de sí misma hacia los foros de la confrontación racional con posiciones no católicas (ateas, agnósticas, islámicas, judías, etc.) o cuasicatólicas (v.gr., el catolicismo disidente dentro de la Iglesia).

${ }^{30}$ Véase MacIntyre, A., cit. (n. 29), p. 12; MacIntyre, Alasdair, Moral Relativism, Truth and Justification, en: KNIGHT, Kelvin (editor), The MacIntyre Reader (Notre Dame, University of Notre Dame Pres, 1998), p. 205; y MacIntyre, Alasdair, After Virtue. A Study in Moral Theory (3a edición, Notre Dame, University of Notre Dame Press, 2007), p. 247.

${ }^{31}$ La metáfora del poliedro está tomada de la Exhortación apostólica "Evangelii gaudium" del papa Francisco I (Ciudad del Vaticano, Editrice Vaticana, 2013), n. 236.

${ }^{32}$ Encíclica "Fides et ratio" del papa Juan Pablo II (Ciudad del Vaticano, Editrice Vaticana, 1998), n. 42. 


\section{IDENTIDAD Y MISIÓN DE LAS UNIVERSIDADES CATÓLICAS: UN ANÁLISIS JURÍDICO}

Octavio N. Derisi observa que, como enseña la filosofía clásica, la causa final determina al modo de ser de una cosa, también de una realidad cultural como la universidad: "una cosa está bien constituida cuando responde al fin para el que ha sido hecha"33. "Por consiguiente, si queremos saber qué es la universidad, cuál es su esencia o naturaleza y su organización, debemos comenzar por determinar el fin de la misma" ${ }^{4}$. El fin de la universidad es, desde sus orígenes con las cuatro facultades clásicas (artes, teología, derecho y medicina), "la investigación y transmisión o docencia de la verdad en un nivel superior de la ciencia o develación de sus causas en todas sus manifestaciones particulares [...] y en su visión sapiencial de la Filosofía y de la teología cristianas [...] que las integra o unifica en el plano fundamental de sus últimas causas" ${ }^{35}$.

Esta definición teleológica recoge, efectivamente, la esencia de la universidad clásica, según su origen en la Cristiandad. Esta identidad originaria de la institución -según hemos visto- presupone la verdad de la fe católica -un presupuesto que actualmente no es culturalmente válido ${ }^{36}-$, y solamente puede ser plenamente realizada por una universidad sustancialmente católica.

En la medida que el presupuesto de la fe se rechaza o se pone entre paréntesis, se reduce la finalidad de la universidad a la investigación y transmisión de los conocimientos científicos -suele omitirse la expresión problemática "la verdad" - y la formación profesional superior de los estudiantes. La universidad secular, que deja al ámbito privado -incluso respetuosamente- el cultivo de las convicciones religiosas y no asume la verdad de ninguna de ellas, nos parece, sin embargo, más universal de facto: ella acoge en su seno, en un plano de igualdad fundamental, a todos los ciudadanos sin distinguir entre ellos según su identidad religiosa y sin favorecer por principio las convicciones religiosas o ideológicas de ninguna persona o grupo. Tal es el ideal declarado de la laicidad o no confesionalidad, aunque, en realidad, suele haber una confesionalidad liberal laicista o incluso un control de estas instituciones por parte de grupos ideológicos secularistas, frecuentemente en una proporción

${ }^{33}$ De Risi, Octavio, Naturaleza y vida de la universidad (Buenos Aires, El Derecho, 1980), p. 19.

${ }^{34}$ Ibíd., p. 20.

${ }^{35}$ Ibíd. El original en cursiva, que he eliminado.

${ }^{36}$ Carta apostólica "Porta fidei" del papa Benedicto XVI (Ciudad del Vaticano, Editrice Vaticana, 2011), n. 2. 
muy superior a su representatividad respecto del conjunto de la sociedad. La frecuencia de este hecho en el mundo lleva a pensar que no es casual.

Sea como fuere, las diferencias identitarias formales o explícitas, a diferencia de las de facto o implícitas, se reflejan en los estatutos jurídicos de las universidades actualmente existentes. Desde la perspectiva que aquí adoptamos -jurídica y, a la vez, interesada en las universidades católicas desde la perspectiva doctrinal-, podemos distinguir diversos tipos de universidades, independientemente de si se llaman o no "universidades". En algunos países, como Estados Unidos, las instituciones de educación superior (post-secundaria o terciaria) que no ofrecen doctorados de investigación, o que son de carreras tecnológicas, reciben otros nombres (v.gr., "colleges", "institutes"), pero son realmente universidades en el sentido amplio que aquí nos interesa. Concretamente, los tipos que cabe distinguir a estos efectos son los siguientes:

i) Universidades civiles estatales, es decir, fundadas o asumidas por el Estado conforme a su propia legislación, que a veces les otorga gran autonomía (por ejemplo, la Universidad Nacional Autónoma de México, la Universidad de Chile, etc.).

ii) Universidades civiles libres, es decir, aquellas fundadas y controladas por miembros - personas y grupos- de la sociedad civil, conforme al derecho secular vigente, con la orientación académica, ideológica o religiosa que ellos deciden darles en ejercicio de sus derechos fundamentales (libertad de enseñanza; de pensamiento, conciencia y religión; de emprendimiento económico; etc.) y con pleno respeto del orden público y de las competencias estatales. Algunas de ellas son sustancialmente católicas, como otras son sustancialmente liberales, masónicas, marxistas, evangélicas o islámicas. A veces se las denomina, impropiamente, "universidades privadas". Esta impropiedad procede de confundir lo público con lo estatal, y de olvidar que la finalidad define la esencia de una cosa. En este caso, la finalidad esencial de las universidades estatales y de las libres es la misma, y es evidentemente pública - o sea, abierta a todos, ordenada al bien común, compartida, etc.- : conocer, investigar y enseñar la ciencia y la cultura; formar a las nuevas generaciones de ciudadanos en las profesiones superiores o científicas; y orientar todo eso al servicio de la sociedad como un todo ${ }^{37}$.

iii) Universidades y facultades eclesiásticas, cuya finalidad es investigar y enseñar las ciencias sagradas o vinculadas con lo sagrado ${ }^{38}$, especialmente -aunque no exclusivamente- a quienes cursan los estudios eclesiásticos como parte de su preparación para el sacerdocio o la vida reli-

${ }^{37}$ Sobre el carácter público de toda universidad, véanse: ArAncibia, Jaime, Universidad, el genuino significado de lo público, en El Mercurio, 29 de septiembre de 2013, cuerpo A2; y Llano, Alejandro, Repensar la Universidad, en Humanitas, 33 (2004).

${ }^{38}$ Código de Derecho Canónico (1983) c. 815. 
giosa o consagrada. Las universidades y facultades eclesiásticas son erigidas por la Santa Sede y otorgan grados académicos por la autoridad de la Santa Sede.

iv) Las universidades oficialmente católicas, es decir, erigidas o reconocidas como tales por la autoridad eclesiástica ${ }^{39}$.

Una universidad es sustancialmen te católica -o católica en un "sentido material" ${ }^{\prime 40}$ - si "el ideario es católico" ${ }^{31}$ y así es declarado formalmente, aunque no use ni pueda legítimamente usar ese apelativo, por no estar públicamente reconocida como católica por la autoridad eclesiástica competente. Por lo tanto, no llamamos aquí universidades sustancialmente católicas a las que simplemente de facto - por la contingente composición de su profesorado y estudiantado- tienen un ambiente público y una investigación y enseñanza en armonía con la fe católica, sino a las universidades que, llamándose católicas o no, poseen una "inspiración católica, con ideario jurídicamente vinculante ${ }^{42}$. El carácter sustancialmente católico, de iure, y no solo de facto, constituye a la institución en una institución con ideario propio o de tendencia, lo cual conlleva importantes efectos jurídicos en la delimitación de los derechos y deberes de sus miembros y del Estado en relación con la respectiva universidad ${ }^{43}$.

De lo expuesto se sigue que una universidad podría ser católica de facto, porque así lo quieren los que la promueven -y así ha resultado hasta el momento-, sin consecuencias jurídicas, o bien podría ser católica sustancialmente y de iure en cuatro casos fundamentales: $i$ ) universidad estatal confesional en un Estado católico (por ejemplo, en España hasta la Consti-

${ }^{39}$ Código de Derecho Canónico (1983) c. 808.

${ }^{40}$ Hervada, Javier, "Vetera et Nova". Sobre el estatuto de las universidades católicas y eclesiásticas (2a edición, Pamplona, Navarra Gráfica Ediciones, 2005), p. 357.

${ }^{41}$ Ibíd., p. 357. Véase Cito, Davide, Comentario al canon 808, en AA.VV., Comentario exegético al Código de Derecho Canónico ( $3^{a}$ edición, Pamplona, EUNSA, 2002), III,1, p. 268, quien habla de un "concepto sustancial de universidad católica que concierne a sus elementos materiales, y que es aplicable a toda universidad que se proponga una tarea de investigación y de docencia iluminada por la luz del Evangelio, independientemente de su configuración jurídico canónica, que pertenece a un momento posterior. Tal concepto sustancial ocupa una posición preeminente respecto de cualquier otra determinación posterior (Véase Código de Derecho Canónico (1917) c. $1379 \$ 2$ y Código de Derecho Canónico (1983) c. 809)".

${ }^{42}$ Hervada, Javier, "Vetera et Nova”, cit. (n. 40), p. 358.

${ }^{43}$ Entre otras consecuencias, da una prioridad a la libertad religiosa y de conciencia y de enseñanza de la institución e impone un deber de lealtad a los miembros de la institución. Véase Moreno Botella, Gloria, Organizaciones religiosas y deber de lealtad. El Tribunal Europeo de Derechos Humanos ante las relaciones laborales de contenido ideológico y el derecho a la autonomía e identidad de las iglesias (Madrid, Editorial Académica Española, 2012), pp. 3-22. 
tución de 1978); ii) universidad eclesiástica autónoma -actualmente, solo las universidades Pontificias Romanas ${ }^{44}$ - o facultad eclesiástica integrada en una universidad estatal -como en Alemania- o en una universidad oficialmente católica -como suele suceder en muchas universidades católicas fuera de Roma ${ }^{45}$-; iii) universidad oficialmente católica, porque que así se llama públicamente, que a su vez admite diversas formas de creación o reconocimiento; y iv) universidad civil libre de inspiración católica, que adopta la identidad católica de manera expresa y formal -en sus estatutos o de otra forma jurídicamente válida-, pero que no es oficialmente católica porque ni se llama "católica" ni solicita el reconocimiento por parte de la autoridad eclesiástica ${ }^{46}$.

Una universidad sustancialmente católica de iure podría ver debilitada su identidad católica de facto, con lo cual se debilitaría igualmente el cumplimiento de su misión de servicio a la sociedad civil y a la comunidad católica. El fin de este artículo no es exponer toda la compleja regulación jurídica de los diversos tipos de universidades sustancialmente católicas, sino lo que en justicia es debido -según el derecho vigente y sus fundamentos doctrinales- para definir esa identidad y misión. Con otras palabras, ¿qué exige la justicia -expresada en el derecho vigente- a una universidad sustancialmente católica para que lo sea realmente y cumpla su misión propia?

La respuesta a nuestra pregunta se halla en una multitud de documentos del Magisterio de la Iglesia y en unas pocas normas jurídicas de elevada jerarquía y estabilidad. En el marco de la conmemoración de medio siglo del Concilio Vaticano II y de un cuarto de siglo de la Magna Carta de las universidades católicas (Ex corde Ecclesiae), se comprende que nos refiramos especialmente al Magisterio de ese Concilio y de los pontífices romanos más recientes y a las normas actualmente vigentes, todas posteriores al Vaticano II.

Iñigo Martínez-Echevarría Castillo ${ }^{47}$ ha sintetizado las enseñanzas de Juan Pablo II y Benedicto XVI, así como de los principales documentos del Concilio Vaticano II aplicables a las universidades católicas ${ }^{48}$, de la siguiente manera:

${ }^{44}$ Grocholewsky, Zenon, Università Cattoliche-Universitá Ecclesiastiche, en AA. VV., I valori accademici dell università europea. Atti del seminario di studio promosso in relazione al "processo di Bologna" (Ciudad del Vaticano, Editrice Vaticana, 2007), pp. 9-13.

${ }^{45}$ No conozco algún caso -teóricamente posible- de una universidad civil libre que acoja en su seno una facultad eclesiástica. Sería deseable que así sucediera, en mi opinión, al menos en aquellas que celebran pactos de garantía doctrinal con instituciones de la Iglesia.

${ }^{46}$ Hervada, Javier, “Vetera et Nova”, cit. (n. 40), p. 358.

${ }^{47}$ Martínez-Echevarría, I., cit. (n. 5).

${ }^{48}$ Los principales documentos del Concilio Vaticano II que de alguna manera afec- 
a) La "naturaleza permanente de la Universidad y de su tarea" (Benedicto $\mathrm{XVI})^{49}$ se caracteriza por tres rasgos:

i) Ser una comunidad de personas -la universitas magistrorum et scholarium o universitas personarum ${ }^{50}$ - unida por buscar la verdad en todas sus dimensiones sapienciales y científicas -la universitas scientiarum ${ }^{51}-$, es decir, por tender hacia la unidad de los saberes: toda la verdad sobre todas las $\cos ^{5} s^{52}$. Esta finalidad exige la apertura a la trascendencia para la integración del saber ${ }^{53} ; \mathrm{y}$, por ende, exige positivamente también la presencia de la teología en la comunidad universitaria ${ }^{54}$. De esta descripción normativa se sigue que las universidades sustancialmente católicas -con independencia de su estatuto jurídico-son el caso central o analogado principal de Universidad sin más o a secas, al que se aproximan los casos secundarios más o menos logrados: las universidades civiles o seculares con facultades o estudios de teología, las universidades puramente eclesiásticas -que no pueden ser plenamente universidades, pues les falta todo el mundo universitario secular- y las universidades seculares laicistas, que carecen de estudios teológicos, y que, por razones inversas a las de las universidades eclesiásticas, tampoco pueden ser plenamente universidades.

ii) Ser una comunidad unida por el servicio a la persona y a la sociedad ${ }^{55} ; \mathrm{y}$

iii) Estar dotada de una legítima autonomía respecto de las autoridades civiles y eclesiásticas y de otros intereses distintos de la verdad y la dignidad de la persona humana ( $v . g r$. , intereses particulares de poder, de clase social, de ganancia económica, etc. $)^{56}$.

b) La inspiración cristiana y católica de la tarea universitaria es parte de la misión de la Iglesia respecto del mundo de la cultura y de la universidad en general, y es de la esencia de una universidad católica. Precisamente por su universalidad y su catolicidad, esa inspiración católica conlleva como exigencias "el respeto y el diálogo con las demás tradiciones éticas, humanísticas y religiosas; el carácter prioritario de la acción de los fieles que se dedican

tan a nuestro tema son: "Lumen gentium”, “Christus Dominus", "Dei Verbum”, “Apostolicam actuositatem”, "Dignitatis humanae”, “Ad gentes”, "Gaudium et spes”, "Presbyterorum ordinis" y "Gravissimum educationis". Véase MARTíneZ-EChEVARRía, I., cit. (n. 5), p. 247.

${ }^{49}$ Carta apostólica "Porta fidei" del papa Benedicto XVI (Ciudad del Vaticano, Editrice Vaticana, 2011), n. 11. Véase Martínez-Echevarría, I., cit. (n. 5), p. 76.

${ }^{50}$ Martínez-Echevarría, I., cit. (n. 5), pp. 63-66.

${ }^{51}$ Ibíd., pp. 63-66.

${ }^{52}$ Ibíd., pp. 76-83.

${ }^{53}$ Ibíd.,) pp. 83-88.

${ }^{54}$ Ibíd., pp. 89-94.

${ }^{55}$ Ibíd., pp. 95-105.

${ }^{56}$ Ibíd., pp.105-123. 
profesionalmente a la Universidad; y la presentación científica del mensaje cristiano" 57 . Por eso, se ha de realizar en comunión orgánica entre los pastores (los obispos y sacerdotes) y los fieles laicos ${ }^{58}$.

c) Las universidades sustancialmente católicas pueden buscar una "garantía eclesial civilmente eficaz" de su identidad católica. Esta garantía es canónicamente obligatoria para la enseñanza de las ciencias eclesiásticas ${ }^{59}$. En el caso de las otras ciencias, puede lograrse tal garantía mediante la fórmula jurídica de las universidades oficialmente católicas, que comienzan a fundarse -como hemos visto- desde mediados del siglo XIX, por impulso pontificio, como una nueva forma de contar con universidades en sentido pleno, o sea, autónomas respecto del poder político ${ }^{60}$. Sin embargo, tal garantía eclesial civilmente eficaz también puede conseguirse sin la fórmula jurídica de las universidades oficialmente católicas, en las cuales la entidad eclesiástica -diócesis, persona pública canónica, etc.- parece asumir toda la gestión y la responsabilidad por su universidad. Esta nueva fórmula consiste en que universidades plenamente seculares, promovidas por fieles católicos incluso con la ayuda de no católicos, celebren "acuerdos de garantía doctrinal y moral" ${ }^{\prime 61}$ con una institución eclesiástica (v.gr., una diócesis) que en cuanto tal solamente asume la responsabilidad de "garantizar la orientación doctrinal y moral de la docencia y de la investigación" ${ }^{2}$ y puede naturalmente proporcionar "la oportuna asistencia pastoral"63.

Dejando de lado el análisis de las ventajas e inconvenientes de las diversas formas de garantía ju rídicamente eficaz -con eficacia legal también en el orden civil estatal e internacional-, adecuadamente abordado por MartínezEchevarría $^{64}$, la cuestión de fondo es en qué consiste el ius, el suum, lo debido en justicia comoidentidad y misión de estas universidades sustancialmente católicas, según el derecho canónico vigente. En consecuencia, todo el resto de la responsabilidad moral y jurídica por la gestión de la universidad en sus aspectos materiales, técnicos, económicos, etc., es asumida exclusivamente por las personas -católicas o no- que las fundan con arreglo a las leyes civiles.

\footnotetext{
${ }^{57}$ Ibíd., p. 141; pp. 127-143.

${ }^{58}$ Ibíd., pp. 144-155.

${ }^{59}$ Constitución Apostólica "Sapientia Christiana" del papa Juan Paulo II (Ciudad del Vaticano, Editrice Vaticana, 1979), artículos 2 y 9.

${ }^{60}$ Martínez-Echevarría, I., cit. (n. 5), pp. 175 y siguientes.

${ }^{61}$ Ibíd., p. 220.

${ }^{62}$ Ibíd., p. 220.

${ }^{63}$ Congregación para los Obispos, Directorio para el ministerio pastoral de los Obispos Apostolorum Successores, del 22 de mayo de 2004; al que se remite MARTíneZECHEVARRía, I., cit. (n. 5), pp. 219.

${ }^{64}$ Martínez-Echevarría, I., cit. (n. 5),) pp. 173-229.
} 
A nuestro modo de ver, la identidad y misión de una universidad sustancialmente católica puede caracterizarse de la siguiente manera:

1. ${ }^{\circ}$ Es una autentica universidad vis a vis cualquier institución universitaria no católica: "una comunidad académica, que, de modo riguroso y crítico, contribuye a la tutela y desarrollo de la dignidad humana y de la herencia cultural mediante la investigación, la enseñanza y los diversos servicios ofrecidos a las comunidades locales, nacionales e internacionales" ${ }^{65}$.

2. ${ }^{\circ} \mathrm{Su}$ objetivo es "garantizar de forma institucional una presencia cristiana en el mundo universitario frente a los grandes problemas de la sociedad y de la cultura" ${ }^{66}$.

Aquí, "presencia cristiana” significa "presencia católica”. Podemos afirmarlo con seguridad por dos razones: $i$ ) el mismo documento traduce ese objetivo en unas "características esenciales" que la universidad ha de tener "en cuanto católica" ${ }^{67}$ y ii) la plenitud de la Revelación cristiana, con los medios de la salvación de la única Iglesia de Cristo, solamente subsiste en la Iglesia Católica romana ${ }^{68}$.

3. ${ }^{\circ}$ La universidad católica "inspira y realiza su investigación, la enseñanza y todas las demás actividades según los ideales, principios y actitudes católicos"69. Este rasgo neto, formulado de modo genérico, se concreta en otras cuatro características según la fórmula de Ex corde Ecclesiae en su número 13: "Puesto que el objetivo de una Universidad Católica es el de garantizar de forma institucional una presencia cristiana en el mundo universitario frente a los grandes problemas de la sociedad y de la cultura, ella debe poseer, en cuanto católica, las caracteristicas esenciales siguientes: 1 una inspiración cristiana por parte, no sólo de cada miembro, sino también de la Comunidad universitaria como tal; 2 una reflexión continua a la luz de la fe católica, sobre el creciente tesoro del saber bumano, al que trata de ofrecer una

${ }^{65}$ Constitución Apostólica del papa Juan Pablo II "Ex corde Ecclesiae" (Ciudad del Vaticano, Editrice Vaticana, 1990), n. 12 y artículo 2, \$1. La Constitución Apostólica inspira su definición en la Carta Magna de las Universidades Europeas, Bolonia, Italia, 18-IX-1988, "Principios fundamentales" (véase la nota 14 de Ex corde Ecclesiae), es decir, en un documento compartido por no católicos.

${ }^{66}$ Constitución Apostólica del papa Juan Pablo II "Ex corde Ecclesiae" (Ciudad del Vaticano, Editrice Vaticana, 1990), n. 13.

${ }^{67}$ Ibíd.

${ }^{68}$ Véase la Constitución dogmática del Concilio Vaticano II sobre la Iglesia "Lumen Gentium" (1965), n. 8; en Decreto "Unitatis redintegratio" del Concilio Vaticano II sobre el ecumenismo (1965), n. 3 y la Declaración "Dominus Iesus" de la Congregación para la Doctrina de la Fe sobre la unicidad y universalidad salvifica de Jesucristo y de la Iglesia (2000).

${ }^{69}$ Constitución Apostólica del papa Juan Pablo II "Ex corde Ecclesiae" (Ciudad del Vaticano, Editrice Vaticana, 1990), artículo 2, §2. Énfasis añadido. 
contribución con las propias investigaciones; 3 la fidelidad al mensaje cristiano tal como es presentado por la Iglesia; 4 el esfuerzo institucional al servicio del pueblo de Dios y de la familia humana en su itinerario hacia aquel objetivo trascendente que da sentido a la vida".

Las cuatro características citadas son especialmente exigentes y se desarrollan en los números siguientes de Ex corde Ecclesiae con más detalle: los investigadores "examinan a fondo la realidad con los métodos propios de cada disciplina"70 y procuran hacer un aporte a la in tegración del saber de manera interdisciplinaria, abierta a la perspectiva teológica, haciendo real el dialogo entre fe y razón -que "se encuentran en la única verdad" tando "las implicaciones éticas y morales", una preocupación "particularmente urgente en el campo de la investigación cientifica y tecnológica"72.

4. ' La universidad católica ha de "formar una comunidad auténticamente humana, animada por el espiritu de Cristo" ${ }^{73}$. A partir de una interna unidad, basada en "la común consagración a la verdad" ${ }^{4}$, en la "idéntica visión de la dignidad humana y, en último término, de la persona y del mensaje de Cristo"75, esta comunidad "está animada por un espiritu de libertad y de caridad, y está caracterizada por el respeto reciproco, por el diálogo sincero y por la tutela de los derechos de cada uno"76.

5. La comunidad universitaria goza de esa "autonomía que, sobre la base de su mismo concepto fundacional, siempre ha formado parte de su naturaleza de universidad, la cual debe estar vinculada exclusivamente a la autoridad de la verdad. En su libertad frente a autoridades políticas y eclesiásticas la universidad encuentra su función particular, precisamente también para la sociedad moderna, que necesita una institución de este tipo" ${ }^{\text {"77 }}$. Esta autonomía -vinculada a la verdad- ha de manifestarse también "contra la presión del poder y de los intereses"78. También una universidad católica se caracteriza por esa libertad radical en la verdad: la autonomía frente a la autoridad civil y eclesiástica, sin desconocer las competencias propias -limitadas- de esas autoridades para salvaguardar el bien común temporal, por parte del Estado,

\footnotetext{
${ }^{70}$ Ibíd., n. 15.

${ }^{71}$ Ibíd., n. 17.

${ }^{72}$ Ibíd., n. 18. Véanse nn.14-18.

${ }^{73}$ Ibíd., n. 21.

${ }^{74}$ Ibíd., n. 21.

${ }^{75}$ Ibíd., n. 21.

${ }^{76}$ Ibíd., n. 21.

${ }^{77}$ Discurso del papa Benedicto XVI preparado para el encuentro con la Universidad de Roma "La Sapienza" (17 de enero de 2008), párrafo 2.

${ }^{78}$ Ibíd., párrafo 10.
} 
y el bien común eclesial -especialmente la integridad de la fe y la moral- por parte de la jerarquía eclesiástica.

Ex corde Ecclesiae reconoce esa autonomía, así como la libertad académica "dentro de las exigencias de la verdad y del bien común"79.

6. ${ }^{\circ}$ Finalmente, la misión fundamental de servicio de la universidad católica consiste en aportar "sus características especificas y su finalidad" 80 -su real y vivida identidad católica- a "la constante búsqueda de la verdad mediante la investigación, la conservación y la comunicación del saber para el bien de la sociedad"81. Ex corde Ecclesiae se detiene en algunas concreciones de esta misión de servicio, entre las cuales cabe destacar algunas especialmente vinculadas con su identidad católica:

i) Investigar "las raíces y las causas" ${ }^{82}$-especialmente éticas y religiosas"de los graves problemas contemporáneos, tales como la dignidad de la vida humana, la promoción de la justicia para todos, la calidad de vida personal y familiar, la protección de la naturaleza, la búsqueda de la paz y de la estabilidad política, una distribución más equitativa de los recursos del mundo y un nuevo ordenamiento económico y político que sirva mejor a la comunidad humana a nivel nacional e internacional" ${ }^{83}$.

ii) Examinar y evaluar desde el punto de vista cristiano "los valores y normas dominantes en la sociedad y en la cultura modernas", y comunicar los "principios éticos y religiosos que den pleno significado a la vida humana" $"$.

iii) "El espíritu cristiano de servicio a los demás en la promoción de la justicia social reviste particular importancia para cada Universidad Católica y debe ser compartido por los profesores y fomentado entre los estudiantes. La Iglesia se empeña firmemente en el crecimiento integral de todo hombre y de toda mujer. El Evangelio, interpretado a través de la doctrina social de la Iglesia, llama urgentemente a promover "el desarrollo de los pueblos, que luchan por liberarse del yugo del hambre, de la miseria, de las enfermedades endémicas y de la ignorancia; de aquellos que buscan una participación más amplia en los frutos de la civilización y una valoración más activa de sus cualidades humanas; que se mueven con decisión hacia la meta de su plena realización". La Universidad Católica siente la responsabilidad de contribuir concretamente al progreso de la sociedad en la que opera:

${ }^{79}$ Constitución Apostólica del papa Juan Pablo II "Ex corde Ecclesiae" (Ciudad del Vaticano, Editrice Vaticana, 1990), n. 29. Véase también su artículo 2, \$5.

${ }^{80}$ Ibíd., n. 30.

${ }^{81}$ Ibíd., n. 30.

${ }^{82}$ Ibíd., n. 32.

${ }^{83}$ Ibíd., n. 32.

${ }^{84}$ Ibíd., n. 33. 
podrá buscar, por ejemplo, la manera de hacer más asequible la educación universitaria a todos los que puedan beneficiarse de ella, especialmente a los pobres o a los miembros de grupos minoritarios, que tradicionalmente se han visto privados de ella. Además, ella tiene la responsabilidad -dentro de los límites de sus posibilidades- de ayudar a promover el desarrollo de las Naciones emergentes" $\$ 5$.

iv) Ofrecer la pastoral universitaria ${ }^{86}$.

v) Promover -desde sus competencias propias como universidad- "un fructuoso diálogo entre el Evangelio y la cultura" ${ }^{87}$, para "discernir los aspectos positivos y negativos" de cada una ${ }^{88}$, incluyendo los de la cultura moderna ${ }^{89}$, e impulsar el diálogo entre pensamiento cristiano y ciencias modernas ${ }^{90}$ y el diálogo ecuménico ${ }^{91}$.

vi) Finalmente, la universidad católica ha de contribuir "según su propia naturaleza" ${ }^{\text {"2 }}$-i.e., como universidad: con su investigación, su docencia, etc.- a la misión evangelizadora de la Iglesia, mediante "un vital testimonio de orden institucional de Cristo y de su mensaje, tan necesario e importante para las culturas impregnadas por el secularismo o allí donde Cristo y su mensaje no son todavía conocidos de hecho"'

Atendida la particular vinculación de la Iglesia con la verdad natural y revelada - por su munus docendi94 - y de la Universidad Católica con la misión de investigar y enseñar esa verdad, se entiende que, en el contexto de culturas no cristianas o postcristianas, el magisterio pontificio preconice "la investigación realizada a la luz del mensaje cristiano" 95 , así como "la formación dada en un contexto de fe, que prepare personas capaces de un juicio racional y crítico, y conscientes de la dignidad trascendental de la persona human" ${ }^{\prime \prime}$. La dimensión martirial/testimonial de esa enseñanza se expresa en estas palabras: "Si es necesario, la universidad católica deberá tener la valentía de expresar verdades incómodas, verdades que no halagan

${ }^{85}$ Ibíd., n. 34.

${ }^{86}$ Ibíd., n. 41.

${ }^{87}$ Ibíd., n. 43.

${ }^{88}$ Ibíd., n. 44.

${ }^{89}$ Ibíd., n. 45.

${ }^{90}$ Ibíd., n. 46.

${ }^{91}$ Ibíd., n. 47.

${ }^{92}$ Ibíd., n. 49.

${ }^{93}$ Ibíd., n. 49.

${ }^{94}$ Errázuriz, Carlos, La parola di Dio quale bene giuridico ecclesiae. Il munus docendi della Chiesa (Roma, EDusC, 2012), pp. 141-156.

${ }^{95}$ Constitución Apostólica del papa Juan Pablo II "Ex corde Ecclesiae" (Ciudad del Vaticano, Editrice Vaticana, 1990), n. 49.

${ }^{96}$ Ibíd. 
a la opinión pública, pero que son también necesarias para salvaguardar el bien auténtico de la sociedad"97.

Una vez clarificada normativamente dicha identidad y misión, que es el deber-ser más radical de una universidad católica, a la luz de los principales documentos jurídicos y magisteriales precedentes al actual pontificado, revisaremos sucintamente las principales enseñanzas del Papa Francisco sobre esta materia.

\section{LA IDENTIDAD CATÓLICA REFORZADA POR FRANCISCO}

El papa Francisco ha ofrecido también un renovado refuerzo -magisterial y espiritual- a esta configuración de la identidad y misión de las universidades católicas. Por una parte, el Papa describe una crisis múltiple -económica y financiera, pero también ecológica, educativa, moral, humana-, no como una tragedia capaz de abatirnos, sino como una serie de peligros y de oportunidades. Entonces nos previene contra el "pesimismo respecto de toda posibilidad de intervención eficaz", un "pensar en clave apocaliptica", que "lleva a una suerte de parálisis de la inteligencia y de la voluntad" 100 o a huir y "lavarse las manos" como Pilatos ${ }^{101}$. El Papa abre caminos de esperanza. "Y aquí es precioso el rol de la Universidad. La universidad como lugar de elaboración y transmisión del saber, de formación en la 'sabiduría' en el sentido más profundo del término, de educación integral de la persona"102. El Papa propone, entonces, tres tareas para la universidad: i) afrontar la realidad sin "lecturas ideológicas o parciales", sino con discernimiento "sobre la base de criterios éticos y espirituales" ${ }^{103}$; ii) promover la cultura del encuentro y del diálogo abierto a la fe y a la trascendencia; y (iii) formar para la solidaridad ${ }^{104}$. Todo esto han de acometerlo los universitarios -decía Francisco I al Consejo Directivo de la Universidad de Notre Dame- "abriendo su mente y su corazón a la admirable continuidad entre la fe de los santos Pedro y Pablo, la de los confesores y los mártires de toda época, y la fe católica transmitida a ustedes en la familia, la escuela y la parroquia"105.

${ }^{97}$ Ibíd., n. 31.

${ }^{98}$ Encuentro del papa Francisco con el mundo de la cultura en el Aula Magna de la Pontificia Facultad Teológica de Cerdeña (22 de septiembre de 2013).

${ }^{99}$ Ibíd.

${ }^{100}$ Ibíd.

${ }^{101}$ Ibíd.

${ }^{102}$ Ibíd.

${ }^{103}$ Ibíd.

${ }^{104}$ Ibíd.

${ }^{105}$ Discurso del papa Francisco a una delegación de la University of Notre Dame de Indiana, Estados Unidos (30 de enero de 2014). 
El papa alaba el "compromiso con la educación religiosa de los jóvenes y con la enseñanza de un saber inspirado por la confianza en la armonía entre la fe y la razón en la búsqueda de la verdad y de la rectitud"106.

Particularmente iluminadoras son las palabras con que el Romano Pontífice defiende el objetivo original de la universidad de Notre Dame: "La inspiración que guio al padre Edward Sorin y a los primeros religiosos de la Congregación de la Santa Cruz al instituir la Universidad de Notre Dame du Lac sigue siendo central, en las cambiantes circunstancias del siglo XXI, por la identidad que caracteriza a la Universidad y su servicio a la Iglesia y a la sociedad americana" 107 . Todavía más, el impuso apostólico de un discipulado misio n ero gozoso de anunciar el Evangelio "debería serpercibido de un modo del todo especial en las universidades católicas, que, por su misma naturaleza, están comprometidas a mostrar la armonía entre la fe y la razón y a poner en evidencia la relevancia del mensaje cristiano para una vida vivida en plenitud y en la autenticidad" 108 . En este punto, el papa se remite a un largo pasaje de Evangelii gaudium, que vale la pena citar en su integridad: "El anuncio a la cultura implica también un anuncio a las culturas profesionales, cientificas y académicas. Se trata del encuentro entre la fe, la razón y las ciencias, que procura desarrollar un nuevo discurso de la credibilidad, una original apologética que ayude a crear las disposiciones para que el Evangelio sea escuchado por todos. Cuando algunas categorias de la razón y de las ciencias son acogidas en el anuncio del mensaje, esas mismas categorias se convierten en instrumentos de evangelización; es el agua convertida en vino. Es aquello que, asumido, no sólo es redimido sino que se vuelve instrumento del Espiritu para iluminar y renovar el mundo./ Ya que no basta la preocupación del evangelizador por llegar a cada persona, y el Evangelio también se anuncia a las culturas en su conjunto, la teología - no sólo la teología pastoral-en diálogo con otras ciencias y experiencias humanas, tiene gran importancia para pensar cómo hacer llegar la propuesta del Evangelio a la diversidad de contextos culturales y de destinatarios. La Iglesia, empeñada en la evangelización, aprecia y alienta el carisma de los teólogos y su esfuerzo por la investigación teológica, que promueve el diálogo con el mundo de las culturas y de las ciencias. Convoco a los teólogos a cumplir este servicio como parte de la misión salvifica de la Iglesia. Pero es necesario que, para tal propósito, lleven en el corazón la finalidad evangelizadora de la Iglesia y también de la teología, y no se contenten con una teología de escritorio./ Las Universidades son un ámbito privilegiado para pensary desarrollar este empeño evangelizador de un modo interdisciplinario e integrador. Las escuelas católicas,

${ }^{106}$ Ibíd.
${ }^{107}$ Ibíd.
${ }^{108}$ Ibíd. 
que intentan siempre conjugar la tarea educativa con el anuncio explícito del Evangelio, constituyen un aporte muy valioso a la evangelización de la cultura, aun en los paises y ciudades donde una situación adversa nos estimule a usar nuestra creatividad para encontrar los caminos adecuados"109.

Un buen número de universidades católicas fueron fundadas en el siglo XIX o a comienzos del siglo XX, pero su motivación original sigue vigente y es la inspiración auténtica para mejorar su identidad como instituciones católicas. El Papa afirma que "es esencial un testimonio valiente de las universidades católicas respecto a la enseñanza moral de la Iglesia y la defensa de la libertad de apoyar tales enseñanzas, en cuanto proclamadas con autoridad por el magisterio de los pastores, precisamente en y a través de las instituciones formativas de la Iglesia"110. A la luz de la vacilaciones de la universidad de Notre Dame ${ }^{111}$, también se aquilata la paternal invitación del papa a que la universidad "continúe ofreciendo su testimonio inequivoco e indispensable sobre este aspecto de su fundamental identidad católica, especialmente frente a los intentos, de cualquier parte que procedan, de diluirla. Y esto es importante: la identidad propia, como se quiso desde el inicio. Defenderla, conservarla, hacer que siga adelante" 112 .

Más tarde, el jueves 13 de febrero de 2014, el papa Francisco pronunció un importante discurso a los participantes en la reunión plenaria de la Congregación para la Educación Católica ${ }^{113}$, encuentro que se lleva a cabo cada tres años y en el cual se delibera y se adoptan las determinaciones más importantes. El papa menciona los tres temas "imperativos", de los que se está ocupando la reunión ${ }^{114}$ : la preparación de los aniversarios de dos importantes documentos -el 50. de Gravissimum educationis y el 25. de Ex corde Ecclesiae-, mencionada como tercer tema, y la reforma o puesta al día

${ }^{109}$ Exhortación apostólica "Evangelii gaudium" del papa Francisco (Ciudad del Vaticano, Editrice Vaticana, 2013), números 132-134.

${ }^{110}$ Discurso del papa Francisco a una delegación de la University of Notre Dame de Indiana, Estados Unidos (30 de enero de 2014).

${ }^{111}$ Me refiero a su tolerancia de actuaciones contrarias a la fe y a la moral en su campus; a la enseñanza heterodoxa, al doctorado honoris causa otorgado a un Presidente pro-aborto, etc. Véase la sustanciación de estos hechos por un miembro de la misma Universidad, sacerdote de la Congregación de la Santa Cruz: Misca Miscamble, Wilson, For Notre Dame. Battling for the Heart \& Soul of a Catholic University (South Bend, St. Agustine's Press, 2013), pp. 127-128.

${ }^{112}$ Discurso del papa Francisco a una delegación de la University of Notre Dame de Indiana, Estados Unidos (30 de enero de 2014). Énfasis añadido.

${ }^{113}$ Discurso del papa Francisco a los participantes en la plenaria de la Congregación para la Educación Católica (13 de febrero de 2014).

${ }^{114}$ Ibíd., párrafo 2. 
("aggiornamiento") de la Constitución Apostólica Sapientia christiana ${ }^{115}$, mencionada en primer lugar, son asuntos relativos a determinados documentos, ya magisteriales, ya jurídicos. También se estudia desde hace años -aunque el Papa no la menciona- la reforma de Ex corde Ecclesiae. Toda esta labor, a ese alto nivel -magisterial y normativo-, si se concluye con éxito (vale decir, con un magisterio más profundo y actual y con normas más eficaces), debería repercutir en una mejora de la identidad católica de las instituciones. Sin embargo, el Papa menciona expresamente, como segundo tema, "la consolidación de la identidad de las universidades católicas" 116 . Se trata de un tema práctico: no de producir más documentos, sino de lograr un objetivo que, a la luz de la investigación sociológica reciente ${ }^{117}$, nos parece urgente. El papa Francisco habla, con optimismo y en términos positivos, de consolidar la identidad, pero las situaciones de debilitamiento son de muy diversos grados, muy graves en ciertos casos.

El Papa, recordando que "la educación católica es uno de los desafíos más importantes de la Iglesia, empeñada hoy en realizar la nueva evangelización en un contexto histórico y cultural en constante transformación", llama la atención sobre tres aspectos:

a) El "valor del diálogo en la educación" 118 , tanto en la escue$\mathrm{la}^{119}$ como en la universidad, que "son frecuentadas por muchos alumnos

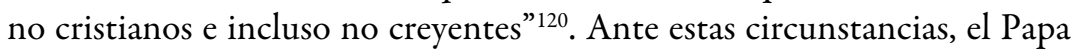
destaca que no son inéditas -se parecen a lo que sucedió a Jesús- y enseña lo siguiente: "Jesús comenzó a anunciar la buena nueva en la 'Galilea de las gentes', encrucijada de personas de diferentes razas, culturas y religiones. Este contexto se parece por ciertos aspectos al mundo de hoy. Los profundos cambios que han llevado a la difusión cada vez más amplia de sociedades multiculturales exigen a quienes trabajan en el sector escolar y universitario implicarse en itinerarios educativos de confrontación y diálogo, con una fidelidad valiente e innovadora que conjugue la identidad católica con las distintas "almas" de la

${ }^{115}$ La Constitución Apostólica "Sapientia Christiana" del papa Juan Pablo II (Ciudad del Vaticano, Editrice Vaticana, 1979) es la ley fundamental de las universidades y facultades eclesiásticas, por lo cual su reforma afectará también a las universidades no eclesiásticas -como muchas universidades oficialmente católicas- que acogen en su seno o alojan facultades eclesiásticas, especialmente de Teología.

${ }^{116}$ Discurso del papa Francisco a los participantes en la plenaria de la Congregación para la Educación Católica (13 de febrero de 2014), párrafo 2.

${ }^{117}$ Véase también la preocupante situación descrita por MOREy y Piderit (2006) pp. 49-58,

${ }^{118}$ Discurso del papa Francisco, cit. (n. 116), párrafo 3.

${ }^{119}$ El papa se remite al documento reciente de la Congregación para la Educación Católica, Educar al diálogo intercultural en la escuela católica (2013).

${ }^{120}$ Discurso del papa Francisco, cit. (n. 116), párrafo 3. 
sociedad multicultural. Pienso con aprecio en la contribución que ofrecen los institutos religiosos y las demás instituciones eclesiales mediante la fundación y la gestión de escuelas católicas en contextos de acentuado pluralismo cultural y religioso" 121.

b) La "preparación cualificada de formadores"122. Aunque el Papa tiene en mente, sobre todo, las escuelas, estimo que sus palabras valen, $m u$ tatis mutandis, para las universidades e instituciones de educación superior: "Quiero limitarme a recordar los rasgos de la figura del educador y de su tarea especifica. Educar es un acto de amor, es dar vida. Y el amor es exigente, pide utilizar los mejores recursos, despertar la pasión y ponerse en camino con paciencia junto a los jóvenes. En las escuelas católicas el educador debe ser, ante todo, muy competente, cualificado y, al mismo tiempo, rico en humanidad, capaz de estar en medio de los jóvenes con estilo pedagógico para promover su crecimiento humano y espiritual. Los jóvenes tienen necesidad de calidad en la enseñanza $y$, a la vez, de valores, no sólo enunciados sino también testimoniados. La coherencia es un factor indispensable en la educación de los jóvenes. Coherencia. No se puede hacer crecer, no se puede educar sin coherencia: coherencia, testimonio./ Por eso el educador necesita, él mismo, una formación permanente. Es imprescindible, pues, invertir para que los profesores y los directivos mantengan su profesionalidad y también su fe y la fuerza de sus motivaciones espirituales. $Y$ también en esta formación permanente me permito sugerir la necesidad de retiros y ejercicios espirituales para los educadores. Es hermoso organizar cursos sobre este o aquel tema, pero también es necesario organizar tandas de ejercicios espirituales, retiros, para rezar. Porque la coherencia es un esfuerzo, pero, sobre todo, es un don y una gracia. Y debemos pedirla" ${ }^{123}$.

Sobre esto, el papa afirma con fuerza: "No se puede improvisar. Debemos trabajar seriamente" 124 . En efecto, puesto que la educación se dirige a una generación que cambia, "todo educador - y toda la Iglesia que es madre educadora-está llamado a cambiar, en el sentido de saber comunicarse con los jóvenes que tiene delante"125.

El profesor en una universidad católica - podemos decir, adaptando las palabras ya transcritas de papa Francisco-, a partir de la conciencia exigente de que educar es un acto de amor y de dar vida, debería esforzase por alcanzar -con la gracia de Dios- estos rasgos:

i) Comprometer con pasión sus mejores recursos en caminar con

${ }^{121}$ Ibíd.

${ }^{122}$ Ibíd.

${ }^{123}$ Ibíd.

${ }^{124}$ Ibíd.

${ }^{125}$ Ibíd. La palabra 'cambiar' está en cursivas en el original. El énfasis en saber comunicarse es mío. 
paciencia junto a los jóvenes: sin perder su identidad de persona adulta y madura en la fe, aprender a hacerse todo para todos ${ }^{126}$ y acompañar con alegría y compresión a sus alumnos.

ii) Ser muy competente y cualificado en su ámbito científico y profesional, para que también en esto muestre metas altas y arrastre a ideales alcanzables, a la vez que proporciona esa sólida preparación científica y profesional a la que los jóvenes tienen derecho.

iii) Ser rico en humanidad para promover el crecimiento humano y espiritual de los jóvenes con una buena pedagogía, estando en medio de ellos.

Estas dos últimas cualidades (b y c) responden a la necesidad de los jóvenes de hallar unidas la calidad de la enseñanza y un conjunto de valores " $n o$ solamente enunciados, sino testimoniados"127. De ahí la fuerza espiritual con que el Papa pide reiterativamente: ¡coherencia!, testimonio, como factor indispensable para educar, hacer crecer a los jóvenes.

iv) Ha de recibir una formación permanente. El Papa dice que se ha de invertir en esto: pienso que, sobre todo, tiem po; pero también trabajo, personal competente para dar esa formación, y dinero, porque en este mundo de hombres - no de ángeles- nada se hace sin destinar los recursos financieros indispensables.

La formación permanente apunta a sostener en un alto nivel la profesionalidad de los profesores -su nivel científico y pedagógico-, y "también su fe y la fuerza de sus motivaciones espirituales" 128 . Por eso, el Santo Padre se permite sugerir -ni siquiera el Papa puede exigir o imponer una forma de vida espiritual a los fieles ${ }^{129}$ - "la necesidad de los retiros y los ejercicios espirituales para los educadores" 130 . Es verdad que está muy bien ofrecer y hacer cursos sobre tal y cual tema, "pero también es necesario hacer cursos de ejercicios espirituales, retiros, ipara rezar!"131. La razón es que esa coherencia -el testimonio de la fe con la vida, del verdadero maestro que cambia para ayudar a crecer a los jóvenes humana y espiritualmente,

${ }^{126}$ Véase 1 Cor. 9,22.

${ }^{127}$ Discurso del papa Francisco, cit. (n. 116).

${ }^{128}$ Ibíd.

${ }^{129}$ Se trata de una consecuencia de ciertos derechos fundamentales de los fieles afirmados por el Magisterio de la Iglesia, como la exigencia de derecho natural y divino de la libertad de las conciencias. Véanse: Código de Derecho Canónico (1983), c. 214; Hervada, Elementos de derecho constitucional canónico (Pamplona, Eunsa, 1987), pp. 128-130; y Del Portillo, Álvaro, Fieles y laicos en la Iglesia: bases de sus respectivos estatutos jurídicos (Pamplona, Eunsa, 1981), pp. 103-104.

${ }^{130}$ Discurso del papa Francisco, cit. (n. 116).

${ }^{131}$ Ibíd. 
caminando con ellos-, aunque es un esfuerzo, "sobre todo es un don y una gracia. ; $Y$ debemos pedirla!"132.

El Santo Padre cifra en la gracia de Dios, operante en la actuación profesional y espiritualmente cualificada de los profesores, la clave del éxito en este desafío educativo. Sin esto, el diálogo verdadero, de que ha tratado antes, sería imposible. Con todo, también es necesario atender al aspecto institucional del desafío.

c) Las instituciones educativas -las escuelas y las universidades católicas y eclesiásticas- y "su responsabilidad de expresar una presencia viva del Evangelio en el campo de la educación, de la ciencia y de la cultura"133.

Así como la falta de coherencia y de testimonio de la fe irán contra la identidad y misión de la universidad católica, también se traicionaría esa misión si la fe permaneciera encerrada en ámbitos eclesiásticos. "Es preciso que las instituciones académicas católicas no se aislen del mundo, sino que entren con valentía en el areópago de las culturas actuales y dialoguen, conscientes del don que tienen para ofrecer a todos" 134 .

La realidad actual de la mayoría de las universidades católicas - no así de las universidades y facultades eclesiásticas- es que no están aisladas del mundo, sino que se han asimilado al mundo -a sus ideologías dominantesy de esta manera han dejado de aportar el don del Evangelio, de su propia identidad, en un diálogo a la vez crítico y constructivo. Esta es una curiosa manera de aislarse del mundo, en otro sentido: encapsular la visión católica en universidades y facultades eclesiásticas, sin que el resto de las facultades aporten esa identidad -visión de fe y razón, en armonía- al ámbito público.

Por último, el papa Francisco ha reforzado también el modo de cumplir esta misión educadora, mediante un discurso oficial y unas palabras i m provisad a $s^{135}$ dirigidas a la reunión plenaria de la Pontificia Comisión para América Latina, que reflexionó sobre el tema: "Transmisión de la fe, emergencia educativa" ${ }^{136}$. El discurso hace referencia a los niños y a los jóvenes. El Papa habla de la transmisión de la fe a los jóvenes en el marco de la actual emergencia educativa. Por eso, aunque sus palabras no son aplicables

${ }^{132}$ Ibíd.

${ }^{133}$ Ibíd.

${ }^{134}$ Ibíd.

${ }^{135}$ Discurso del papa Francisco a los miembros de la Pontificia Comisión para América Latina (28 de febrero de 2014). En realidad, son palabras sumamente pausadas y que reflejan lo repetido por él desde antes de ser elevado al Pontificado Romano. Véase BERGOGLIO, Jorge Mario, Educar: exigencia y pasión: desafíos para educadores cristianos (Buenos Aires, Claretiana, 2006).

${ }^{136}$ Discurso del papa Francisco a los miembros de la Pontificia Comisión para América Latina (28 de febrero de 2014). 
de manera inmediata a los miembros de la comunidad universitaria que no comparten la fe católica y que no quieren transmitirla o recibirla -la Iglesia respeta la libertad de sus conciencias-, de otra parte atañen muy directamente a la mayoría de los profesores, que deben ser católicos, y a muchos estudiantes. El Papa expone tres indicaciones prácticas:

i) Educar es "transmitir contenidos, hábitos, y valoraciones"137. El Papa los llama los "tres pilares" de la transmisión de la fe. "La transmisión tiene que ser de contenidos con valores, valoraciones y hábitos, hábitos de conducta".

Por una parte, ciertamente "hay que dar contenidos básicos"138; pero, "si solamente queremos transmitir la fe con contenidos, será una cosa superficial o ideológica que no va a tener raíces" 139 . Por eso, es necesario además "crear el hábito de una conducta" ${ }^{140} \mathrm{y}$ "crear la recepción de valores" ${ }^{141}$ que preparen y hagan crecer esa fe ${ }^{142}$.

ii) Transmitir a la juventud "el buen manejo de la utopía"143. Según el Papa, "saber conducir y ayudar a crecer la utopía de un joven es una riqueza. Un joven sin utopía es un viejo adelantado, envejeció antes de tiempo" ${ }^{144}$. La cuestión es crucial, como enseña la historia: "Nosotros en América Latina hemos tenido la experiencia de un manejo no del todo equilibrado de la utopía y que en algún lugar, en algunos lugares, no en todos, en algún momento nos desbordó. Al menos en el caso de Argentina podemos decir cuántos muchachos de la Acción Católica, por una mala educación de la utopía, terminaron en la guerrilla de los años 70"145.

Me permito añadir -recuerdo personal- que quienes fuimos jóvenes en los 70 y los 80 del siglo pasado tuvimos que soñar nuestras grandes utopías de fe y de amor, de paz y de progreso, de liberación con respecto al materialismo, resistiendo y muchas veces apartándonos de esos ambientes "católicos" o

\footnotetext{
${ }^{137}$ Ibíd.

${ }^{138}$ Ibíd.

${ }^{139}$ Ibíd.

${ }^{140}$ Ibíd.

${ }^{141}$ Ibíd.

${ }^{142}$ Ibíd. A mi modo de ver, los valores que preparan la transmisión de la fe son los valores humanos, plenamente razonables, accesibles con la luz natural de la razón también para los no creyentes. De ahí la importancia de enseñar el derecho natural a nivel universitario. En cambio, los valores específicamente cristianos (v.gr., las exigencias sublimes del Sermón de la Montaña) son los que hacen crecer esa fe ya recibida, porque son valo res que presuponen la iniciativa y la gracia de Dios, que da el don de la fe.

${ }^{143}$ Discurso del papa Francisco a los miembros de la Pontificia Comisión para América Latina (28 de febrero de 2014).

${ }^{144}$ Ibíd.

${ }^{145}$ Ibíd.
} 
"eclesiásticos" totalmente inficionados de marxismo y de otras ideologías reductoras de la fe a algunos aspectos sociopolíticos ${ }^{146}$.

El Papa identifica el desafío de los educadores católicos: “¿Cómo hago para que esta ilusión que tiene el chico, esta utopía, lo lleve al encuentro con Jesucristo?"'147. Él sugiere que esa u to pía crece bien si va acompañada por la memoria que mira al pasado, el discernimiento en el presente de los signos de los tiempos. De ahí su insistencia en el "encuentro de los viejos y los jóvenes" ${ }^{148}$. El Santo Padre nos pide "ser maestros de discernimiento, consejeros espirituales. Y aquí es importante para la transmisión de la fe de los jóvenes el apostolado cuerpo a cuerpo. El discernimiento en el presente no se puede hacer sin un buen confesor o un buen director espiritual que se anime a aburrirse horas y horas escuchando a los jóvenes"149.

iii) Enfrentar "la cultura del descarte"150. El Santo Padre advierte que "por la economia que se ha implantado en el mundo, donde en el centro está el dios dinero y no la persona humana, todo lo demás se ordena y lo que no cabe en ese orden se descarta"151. Así el papa da un contexto mucho más profundo y dramático a algunos problemas que solemos debatir como su fueran solamente morales: "Se descartan los chicos que sobran, que molestano que no conviene que vengan. Los obispos españoles me decian recién la cantidad de abortos, del número, yo me quedé helado"152. O también: "se descartan los viejos [...] hay eutanasia encubierta"153. Y en este contexto, los jóvenes "nos necesitan más que nunca [...] por la vigencia de transmitir la fe a una juventud que hoy día es material de descarte también" 154 . El papa se refiere a un sistema económico mundial quelleva a "un porcentaje alto de desocupación de los jóvenes"I55: "una generación de jóvenes que no tienen la experiencia de la dignidad", porque, aunque "el pan lo comen" -por la ayuda que reci-

${ }^{146}$ Sobre esta realidad histórica penosa, véase: PORADOwSKI, Miguel, El marxismo invade la Iglesia (Valparaíso, Ediciones Universitarias de Valparaíso, 1974), pp. 73-79; IвÁÑEZ, José Miguel, El marxismo: visión critica (Santiago, Ediciones Universidad Católica de Chile, 1981), p. 282.

${ }^{147}$ Discurso del papa Francisco a los miembros de la Pontificia Comisión para América Latina (28 de febrero de 2014).

${ }^{148}$ Ibíd. El Papa se detiene en cómo los abuelos acogen a los nietos, y en cómo se conservó así la fe en los países del Este de Europa durante la época comunista.

${ }^{149}$ Ibíd.

${ }^{150}$ Ibíd.

${ }^{151}$ Ibíd.

${ }^{152}$ Ibíd.

${ }^{153}$ Ibíd.

${ }^{154}$ Ibíd.

${ }^{155}$ Ibíd. 
ben- no experimentan "la dignidad de ganarse el pan y llevarlo a casa"156. Entonces, "el joven que está sin trabajo tiene anestesiada la utopia o está a punto deperderla"157; y avanza la droga sobre la juventud 158: "Hay todo un armamento mundial de droga que está destruyendo esta generación de jóvenes que está destinada al descarte"159.

Ante un panorama pintado con tintes realistas y trágicos -todos los profesores universitarios sabemos que es verdad lo que dice sobre la droga, "el instrumento de muerte de los jóvenes" ${ }^{160}$, y sobre "la proliferación de adicciones"161 - el papa llama a "darles fe y esperanza"162 porque la "traditio fidei es también traditio spei"163.

$Y$ con la fe y la esperanza, finalmente viene la caridad en la verdad ${ }^{164}$ como síntesis de una identidad católica ofrecida desde la universidad al mundo entero.

\section{BiBLIOGRAFÍA}

Arancibia, Jaime, Universidad, el genuino significado de lo público, en El Mercurio, 29 de septiembre de 2013, cuerpo A2.

Bergoglio, Jorge Mario, Educar: exigencia y pasión: desafios para educadores cristianos (Buenos Aires, Claretiana, 2006).

Bravo Lira, Bernardino, La universidad en la historia de Chile: 1622-1992 (Santiago, Pehuén, 1992).

Carta apostólica "Porta fidei" del papa Benedicto XVI (Ciudad del Vaticano, Editrice Vaticana, 2011).

Catecismo de la Iglesia Católica.

Cito, Davide, Comentario al canon 808, en AA.VV., Comentario exegético al Código de Derecho Canónico (3a edición, Pamplona, EUNSA, 2002), III,1.

Código de Derecho Canónico (1917).

Código de Derecho Canónico (1983).

Congregación para la Educación Católica, Educar al diálogo intercultural en la escuela católica (2013).

Constitución Apostólica del papa Juan Pablo II "Ex corde Ecclesiae" (Ciudad del Vaticano, Editrice Vaticana, 1990).

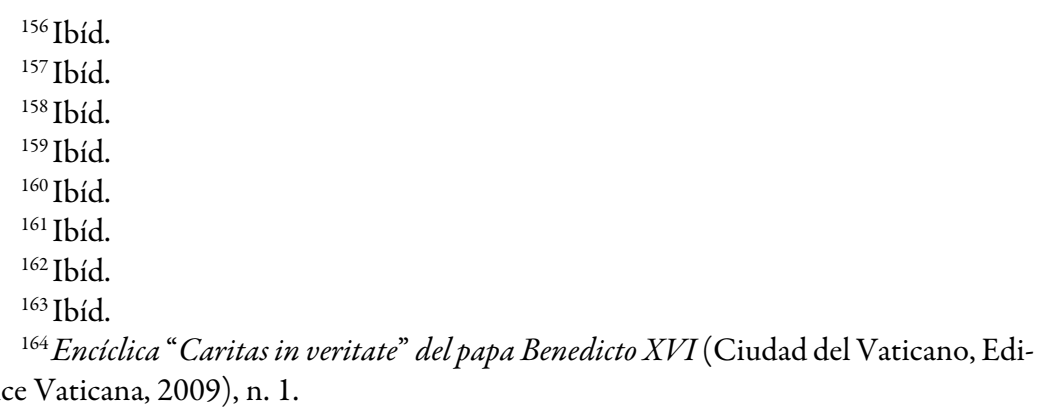


Constitución dogmática del Concilio Vaticano II sobre la Iglesia "Lumen Gentium" (1965). D’Ors, Álvaro, Nuevos papeles del oficio universitario (Madrid, Rialp, 1980).

De La Cruz, Emilio, Lecciones de historia de las universidades (Madrid, Civitas, 1987).

Declaración "Dominus Iesus" de la Congregación para la Doctrina de la Fe sobre la unicidad y universalidad salvifica de Jesucristo y de la Iglesia (2000).

Decreto "Unitatis redintegratio" del Concilio Vaticano II sobre el ecumenismo (1965).

Del Portillo, Álvaro, Fieles y laicos en la Iglesia: bases de sus respectivos estatutos juridicos (Pamplona, Eunsa, 1981).

Derisi, Octavio, Naturaleza y vida de la universidad (Buenos Aires, El Derecho, 1980).

Discurso del papa Benedicto XVI preparado para el encuentro con la Universidad de Roma "La Sapienza" (17 de enero de 2008).

Discurso del papa Francisco a los miembros de la Pontificia Comisión para América Latina (28 de febrero de 2014).

Discurso del papa Francisco a los participantes en la plenaria de la Congregación para la Educación Católica (13 de febrero de 2014).

Discurso del papa Francisco a una delegación de la University of Notre Dame de Indiana, Estados Unidos (30 de enero de 2014).

Encíclica "Caritas in veritate" del papa Benedicto XVI (Ciudad del Vaticano, Editrice Vaticana, 2009).

Encíclica "Fides et ratio" del papa Juan Pablo II (Ciudad del Vaticano, Editrice Vaticana, 1998).

Encuentro del papa Francisco con el mundo de la cultura en el Aula Magna de la Pontificia Facultad Teológica de Cerdeña (22 de septiembre de 2013).

ERrázuriz, Carlos, La parola di Dio quale bene giuridico ecclesiae. Il munus docendi della Chiesa (Roma, EDUSC, 2012).

Exhortación apostólica "Evangelii gaudium" del papa Francisco (Ciudad del Vaticano, Editrice Vaticana, 2013).

Finnis, John, ¿Acaso la universidad corrompe la juventud?, en El Derecho. Diario de Doctrina y Jurisprudencia, 13 (2012) 141.

Grocholewsky, Zenon, Università Cattoliche-Universitá Ecclesiastiche, en AA. VV., I valori accademici dell università europea. Atti del seminario di studio promosso in relazione al "processo di Bologna" (Ciudad del Vaticano, Editrice Vaticana, 2007).

Hervada, Elementos de derecho constitucional canónico (Pamplona, Eunsa, 1987).

Hervada, Javier, "Vetera et Nova”. Cuestiones de derecho canónico y afines (1958-2004) (Pamplona, Eunsa, 2005).

Hervada, Javier, "Vetera et Nova”. Sobre el estatuto de las universidades católicas y eclesiásticas (2a edición, Pamplona, Navarra Gráfica Ediciones, 2005).

IвÁÑ̃E, José Miguel, El marxismo: visión critica (Santiago, Ediciones Universidad Católica de Chile, 1981).

IYANGA, Augusto, Historia de la Universidad en Europa (Valencia, Universitat de Valencia, 2000).

Constitución Apostólica "Sapientia Christiana" del papa Juan Pablo II (Ciudad del Vaticano, Editrice Vaticana, 1979).

Langan, John, Catholic Universities in Church and Society: A Dialogue on "Ex corde Ecclesiae" (Washington, Georgetown University Press, 1993).

Llano, Alejandro, Repensar la Universidad, en Humanitas, 33 (2004).

MacIntyre, Alasdair, After Virtue. A Study in Moral Theory (3a edición, Notre Dame, University of Notre Dame Press, 2007). 
MacInTyre, Alasdair, Moral Relativism, Truth and Justification, en: KNIGHT, Kelvin (edityor), The MacIntyre Reader (Notre Dame, University of Notre Dame Pres, 1998).

MacIntyre, Alasdair, Three Rival Versions of Moral Enquiry. Encyclopaedia, Genealogy and Tradition (Notre Dame, University of Notre Dame Press, 1990).

Martínez-Echevarría, Íñigo, La relación de la Iglesia con la Universidad en los discursos de Juan Pablo II y Benedicto XVI: una nueva aproximación jurídica (Roma, EDUSC, 2010).

Miscamble, Wilson, For Notre Dame. Battling for the Heart \& Soul of a Catholic University (South Bend, St. Agustine's Press, 2013).

Moreno Botella, Gloria, Organizaciones religiosas y deber de lealtad. El Tribunal Europeo de Derechos Humanos ante las relaciones laborales de contenido ideológico y el derecho a la autonomía e identidad de las iglesias (Madrid, Editorial Académica Española, 2012).

Orellana, Miguel, Enriquecerse tampoco es gratis. Educación, modernidad y mercado (Santiago, Editorial Universidad de Santiago de Chile, 2014)..

Parain, Brice, Historia de la filosofía (México, Siglo XXI, 1972), tres volúmenes.

PorAdowski, Miguel, El marxismo invade la Iglesia (Valparaíso, Ediciones Universitarias de Valparaíso, 1974).

VIaL, Juan de Dios, No debemos descuidar la interdisciplinariedad, Revista Universitaria, 50 (1995). 